Forthcoming, Edinburgh Law Review. Available online at:

https://papers.ssrn.com/sol3/papers.cfm?abstract id=3052150

\title{
THE IMPACT OF BREXIT ON ENVIRONMENTAL PROTECTION IN SCOTLAND: SOME EARLY REFLECTIONS
}

\author{
Dr Annalisa Savaresi ${ }^{*}$
}

\section{A. INTRODUCTION}

With much of UK and Scottish environmental law presently originating in Brussels, ${ }^{1}$ experts have long warned of the specific challenges associated with Brexit in this sector. ${ }^{2}$ These concern the loss of the well-established and comparatively stable regulatory, enforcement and support frameworks provided by EU law. While nobody is seriously suggesting that in future the UK and Scotland will be incapable of upholding the rule of law on environmental matters, Brexit will nevertheless entail the loss of a powerful means to scrutinise and enforce environmental protection standards.

Brexit is also likely to entail the loss of access to EU funding and to cooperation programmes that, for good or ill, presently are the lifeblood of UK environmental policy tools, like farm payments, conservation and research-related initiatives. Scotland has benefitted greatly from EU funds for environmental protection and the development of new low carbon technologies, like tidal energy. It also receives a disproportionately large share of EU farm payments. Ahead of Brexit, finding replacements for these means of support will be crucial.

Finally, Brexit raises sensitive questions on the allocation of repatriated EU law and policy-making powers between UK and devolved administrations. When the unifying frame of EU law is removed, existing regulatory and policy differences between Scotland and the rest of the UK - on matters such as genetically modified organisms, fracking and renewable energy - are likely to increase. Such fragmentation in standards across the UK may well threaten the maintenance of present levels of environmental protection. Even more significantly, the spat on the European Union Withdrawal Bill (EUW Bill) has shown that the UK and the Scottish Governments hold rather diverging views on who should assume the regulatory competences presently exercised by the EU after Brexit. ${ }^{3}$

Whoever is in charge of environmental affairs after Brexit, one thing is already clear. The approach envisioned in the EUW Bill could be a viable solution for some areas of

\footnotetext{
${ }^{*}$ Lecturer in Environmental Law, University of Stirling. This article draws on the report A CardesaSalzmann and A Savaresi (eds) The Implications of Brexit for Environmental Law in Scotland, Scottish Universities Legal Network on Europe (2016) available at:

<https://sulne.files.wordpress.com/2016/12/environment-paper-sulne-20161214.pdf. The report includes contributions from scholars from the Universities of Aberdeen, Dundee, Sheffield, Strathclyde and Stirling. The views expressed in the present article, as well as any errors, are the author's alone. The author is grateful to the editors for comments on an earlier version of this paper.

${ }^{1}$ The Department of Environment, Food and Rural Affairs has identified 1,100 pieces of EU legislation and national implementing legislation. See House of Lords, Brexit: Environment and Climate Change (2016) footnote 22. The Scottish Environment Secretary Roseanna Cunningham has claimed that $80 \%$ of Scottish environmental law originates from EU Law. See e.g. 'Brexit Threatens Environmental Ambition' (Scottish Government News, 17 August 2017) available at: https://news.gov.scot/news/brexit-threatensenvironmental-ambition.

${ }^{2}$ See e.g. the repository compiled by the UK Parliament libraries and committees, available at: https:/www.parliament.uk/business/publications/research/eu-referendum/environment-and-science/.

${ }^{3}$ See e.g. 'Amendments to UK Brexit Bill Will Be Proposed' (Scottish Government News, 22 August 2017) available at: https://news.gov.scot/news/amendments-to-uk-brexit-bill-will-be-proposed.
} 
environmental law and policy, but not all. The reason for this lies in the fact that in some areas - such as, for example, chemicals or emission trading - EU law vests a great deal of regulatory power in EU institutions and structures, which will no longer service the UK post Brexit. In these areas, existing arrangements will have to be integrally revisited and replaced.

The challenges associated with the EUW Bill therefore are not just constitutional, but affect the very mechanics of environmental law-making, implementation and enforcement. The UK and Scotland have precious little time to replace existing EU regulatory and enforcement structures to ensure the continuation of present levels of environmental protection after Brexit.

Space precludes a detailed discussion of all emerging environmental challenges. ${ }^{4}$ This article therefore offers some general reflections on the likely implications of Brexit for environmental protection in Scotland and makes recommendations for solutions that may be adopted to address these.

\section{B. ENVIRONMENTAL LAW-MAKING AND ITS ENFORCEMENT}

Scottish and UK law-makers presently are largely norm-takers and implementers of regulatory frameworks more often than not devised and engineered by the EU. This phenomenon is far from unique to EU member states. The role of the EU as a global normmaker and exporter has been widely reported and investigated in the literature, especially in relation to product standards. ${ }^{5}$ So even after Brexit, the UK will remain under pressure to comply with EU standards, whose reach goes well beyond the boundaries of EU membership. ${ }^{6}$

Yet, the assertion that Brexit would not significantly affect environmental protection in the UK has been a common refrain. Broadly speaking, the argument goes as follows: the UK is party to virtually all major international environmental treaties; EU law often merely replicates international obligations; international treaty membership will remain unaffected by Brexit; ergo, the UK will still be subjected to international environmental law commitments after Brexit. Unfortunately, this argument is inaccurate for three main reasons.

Firstly, EU environmental law often builds on and scales up obligations embedded in international environmental agreements, providing more ambitious levels of protection. EU law obligations are furthermore supported by an enforcement machinery which is much more vigorous than that supporting international law obligations. So unplugging from EU law will entail that, at least in some areas, the UK will be subjected both to lesser and less enforceable international environmental obligations. ${ }^{7}$

Secondly, and crucially, the EU is party to numerous international environmental treaties alongside, and sometimes in lieu of, its member states. ${ }^{8}$ The international environmental agreements the EU has concluded in areas exclusively within its competence ${ }^{9}$ and to which the UK is not a party, include, for example, the 1982 Convention for the Conservation of

\footnotetext{
${ }^{4}$ For a summary of these, see Savaresi and Cardesa-Salzmann (above).

${ }^{5}$ See for example the essays collected in WT Douma and S van der Velde (eds) EU Environmental Norms and Third Countries: The EU as Global Role Model? (2013).

${ }^{6}$ As noted for example in J Scott, "From Brussels with Love: The Transatlantic Travels of European Law and the Chemistry of Regulatory Attraction" (2009) 57 Am. J. Com. Law 897.

${ }^{7}$ On the dualist approach and the implementation of international obligations in the UK, see $R v$ Secretary of State for the Home Department ex parte Brind and others [1991] 1 AC 696 (HL) per Lord Bridge.

${ }^{8}$ For a compendium, see: UK Environmental Law Association, Report on Brexit and International Environmental Law (2017).

${ }^{9}$ Pursuant to its powers under article 3 of the Treaty on the Functioning of the European Union (TFEU) (consolidated version) [2012] OJ C 326/47.
} 
Salmon in the North Atlantic ${ }^{10}$ and the 2013 Minamata Convention on Mercury. ${ }^{11}$ After Brexit these international environmental agreements will no longer be formally binding on the UK. Measures implementing the obligations embedded in these treaties may nevertheless live on in UK law, insofar as they survive the exercise of ministerial powers envisioned in the EUW Bill, ${ }^{12}$ for example on contentious matters such as fisheries. ${ }^{13}$ Brexit will thus have the effect of crystallising the obligations enshrined in these international treaties as implemented in UK law at the time of withdrawal, but without taking into account how these obligations may evolve as a result of subsequent treaty amendments and/or practice. This crystallisation is particularly concerning, when one considers, for example, that the Minamata Convention sets out conditions for the handling and trade of mercury, which are likely to be revised and upgraded over time. After Brexit, therefore, the UK should consider ratifying these treaties in its own right, while at the same time closely monitoring measures translating these international obligations into EU law, which typically restrict the import of non-compliant products into the EU market.

The situation is even more complex for so called 'mixed agreements' which have been ratified by both the EU and the UK. ${ }^{14}$ Here the question is not so much whether obligations enshrined in these instruments will continue to apply to the UK after Brexit, but how. International climate change treaties are a case in point. EU member states have opted to implement their commitments under these treaties jointly. ${ }^{15}$ This means, for example, that EU member states have common emission targets under both the Kyoto Protocol and the Paris Agreement, and are jointly responsible under international law for achieving them. Various pieces of EU law provide the details of member states' responsibilities for achieving EU targets. These pieces of EU law have been treated as part and parcel of member states international obligations under the Kyoto Protocol and the same is expected to happen with the Paris Agreement. However, after Brexit, the UK will no longer be bound by EU climate change law. Accordingly, the scope of the UK's international climate change obligations will need to be clarified.

For example, after Brexit the UK could opt to continue implementing its commitments jointly with the EU, similar to European Economic Area (EEA) states Iceland, Lichtenstein and Norway. These states participate in the EU Emission Trading Scheme (EU ETS) and benefit from access to funds supporting the development and application of emission reduction technologies to varying degrees. This arrangement requires EEA states to abide by EU law concerning, inter alia, emission trading, and to contribute funds to schemes devised to support emission reduction technologies. Whether the UK will decide to go down the same route as Iceland, Lichtenstein and Norway remains to be seen. What is certain is that the UK will have to make a decision on these issues and simply cannot expect current arrangements to continue.

Making a decision on emission trading is particularly urgent. The EU ETS presently covers emissions from the UK's most carbon intensive industries. The EU-ETS Directive is also one of the most heavily centralized pieces of EU legislation, which attributes a key role

\footnotetext{
${ }^{10}$ Convention for the Conservation of Salmon in the North Atlantic Ocean (adopted 2 March 1982, in force 1 October 1983).

${ }^{11}$ Minamata Convention on Mercury (adopted 10 October 2013, in force 16 August 2017).

${ }^{12}$ EU Withdrawal Bill (2017) paras 7, 8 and 17.

${ }^{13}$ See e.g. the declarations of the UK Environment Secretary, Michael Gove, as reported in: 'UK to Withdraw from International Fishing Arrangement' (2 July 2017): http://www.bbc.co.uk/news/uk-40471466.

${ }^{14}$ TFEU art 4.

${ }^{15}$ United Nations Framework Convention on Climate Change (adopted 9 May 1992, in force 21 March 1994) Declaration by the EU; Kyoto Protocol to the United Nations Framework Convention on Climate Change (adopted 11 December 1997, in force 16 February 2005) Declaration by the EU; Paris Agreement (adopted 12 December 2015, in force 4 November 2016) Declaration by the EU.
} 
to EU institutions. Should the UK leave the EU ETS, it would have to decide how to do so without compromising the interests of UK installations presently holding EU ETS allowances. The EU is already considering measures to prevent UK installations from selling off large amounts of allowances they will no longer be required to hold after Brexit. If the UK leaves the EU in 2019 without an agreement on how to handle this specific issue, the EU is planning to void all allowances auctioned by the UK since January $2018 .{ }^{16}$ This would have the effect of zeroing the value of allowances held by UK installations, engendering non insignificant financial losses.

At the internal level, given that the EU ETS covers the most polluting installations in the UK, its replacement is essential to ensure environmental protection after Brexit. Arguably, these important law and policy-making decisions ought to be taken with the involvement of the UK Parliament, ${ }^{17}$ and in consultation with devolved administrations, rather than by the exercise of ministerial powers under the EUW Bill alone. ${ }^{18}$

Furthermore, the EU ETS covers a sizeable share of Scotland's emissions, ${ }^{19}$ making it an important means to achieve the targets enshrined in the Climate Change (Scotland) Act 2009. Present constitutional arrangements limit Scotland's powers to remain within the EU ETS, if it so desires. In the context of the ongoing EUW Bill debate, Scotland could demand the devolution of powers to negotiate and conclude international agreements that relate to the exercise of devolved competences. Pursuant to these new powers, Scotland could join the EU ETS and/or other EU schemes aimed to support climate action. While there are no precedents for adhesion to the EU ETS by subnational entities, some EU cooperation programmes already include self-governing territories that are not within the EU, like the Faroe Islands and Greenland. ${ }^{20}$

More generally, the implementation of international climate change obligations after Brexit raises the question of the role of devolved administrations in determining the scope of the UK's climate action. The Paris Agreement requires each Party to submit a 'nationally determined contribution' (NDC). ${ }^{21}$ NDCs contain the details of action to contribute to keeping the global temperature increase within the two degrees Celsius goal enshrined in the Paris Agreement. While the UK's NDC is presently incorporated in that of the EU, after Brexit the UK will have to prepare and submit its own NDC. The process of drafting an NDC will be a novel experience for the UK, and raises the question of devolved administrations' involvement in the exercise of the UK's regained powers on climate law and policy. The concerted exercise of these powers is likely to be particularly tricky on matters where Westminster and Holyrood manifestly have different priorities, such as renewable energy.

This intricate scenario is further complicated by the question of enforcement. EU law comes equipped with a supranational supervision and enforcement machinery that has contributed to the enhancement of environmental protection standards across the $\mathrm{EU}^{22}$ and in the UK, in areas such as air pollution, water quality, and waste. ${ }^{23}$

\footnotetext{
${ }^{16}$ See Amendments adopted by the European Parliament on 13 September 2017 on the proposal for a regulation of the European Parliament and of the Council amending Directive 2003/87/EC to continue current limitations of scope for aviation activities and to prepare to implement a global market-based measure from 2021, Amendment 27.

${ }^{17}$ As suggested also in UKELA (n 8) 51.

${ }^{18}$ House of Lords (n 1) 187.

${ }^{19}$ See Scottish Government, Scottish Greenhouse Gas Emissions 2015.

${ }^{20}$ See e.g. J Hartmann, The Faroe Islands: Possible Lessons for Scotland in a New Post-Brexit Devolution Settlement (2017) available at: https://papers.ssrn.com/abstract=2909543.

${ }^{21}$ Paris Agreement art 4.2.

${ }^{22}$ See e.g. European Commission, Directorate General for the Environment, Study to Assess the Benefits Delivered Through the Enforcement of EU Environmental Legislation' (2016).

${ }^{23}$ See House of Lords (n 1) at 66-71.
} 
Enforcement of EU law chiefly rests on the supervisory powers of the EU Commission, which has the power to bring member states before the Court of Justice of the EU (CJEU). If found to be in breach, the member state can be asked to pay fines until the compliance issue has been resolved. In addition to the enforcement powers of the Commission, members of the public and pressure groups can initiate legal action before member state courts to request compliance with EU law. Conversely, the EUW Bill explicitly excludes UK liability to pay compensation to individuals who have suffered loss by reason of failure to implement EU law properly. ${ }^{24}$

UK authorities have simply become accustomed to being under the EU Commission and the CJEU's scrutiny, and the threat of economic penalties associated with these. Conversely, after Brexit, UK citizens will only be able to access national courts to complain about breaches of domestic environmental law. Coupled with the prohibitive costs of public interest litigation in the UK, it is hardly a surprise that numerous experts have identified the loss of scrutiny over the enforcement of environmental standards as a pressing concern associated with Brexit. ${ }^{25}$

\section{CONCLUSIONS: GETTING READY FOR BREXIT}

The complexities associated with the repatriation of EU powers require particular vigilance in order to ensure that environmental protection does not become an unintended casualty of Brexit. To address the manifold challenges associated with Brexit in the environmental sector, the Scottish Government and Parliament would be well advised to consider the following.

Firstly, it seems necessary to develop an understanding of areas where urgent action is needed in order to replace EU environmental law, policy and support frameworks ahead of Brexit, which are of specific Scottish interest. A corollary of this is the need to identify areas where a UK-wide approach may be necessary.

Secondly, Scotland should identify areas where greater devolved powers are needed to effectively exercise its competences on environmental matters after Brexit. These may include some legal capacity to enter into international agreements addressing specific Scottish interests, such as fisheries.

Thirdly, links with regional and international bodies dealing with cooperation and capacity-building should be developed and strengthened, so as ensure that Scotland remains involved in transnational environmental protection debates after Brexit.

Fourthly, avenues to ensure enhanced supervision of the implementation and enforcement of environmental laws after Brexit should be explored, giving consideration to proposals coming from civil society in this connection. ${ }^{26}$

These actions would assist in ensuring that Scotland is an informed participant in the debate over the future of environmental protection in the UK after Brexit, keeping the UK Government under scrutiny, especially in the context of the exercise of the sweeping ministerial powers envisioned in the EUW Bill.

\footnotetext{
24 EU Withdrawal Bill (2017) Schedule 1.

${ }^{25}$ House of Lords (n 1) at 76-85.

${ }^{26}$ See submissions collected in Scottish Government, Developments in Environmental Justice in Scotland. Consultation Analysis and Scottish Government Response (2017).
} 